\title{
Human Periodontal Cells Initiate Mineral-Like Nodules In Vitro
}

\author{
Nilda Arceo ${ }^{*}$ John J. Sauk, ${ }^{\dagger}$ Jennifer Moehring, ${ }^{\dagger}$ Ruth A. Foster, ${ }^{\ddagger}$ and Martha J. \\ Somerman ${ }^{\ddagger}$
}

A PRIMARY OBJECTIVE IN THE TREATMENT of periodontal diseases is the regeneration of the mineralized and soft connective tissue components of the attachment apparatus. Current theories suggest the cells of the periodontium have the capacity, when appropriately triggered, to actively participate in restoring connective tissues, including mineralized tissues. To evaluate further the role of such cells in periodontal homeostasis, periodontal ligament (PDL) cells and gingival fibroblasts (GF) were cultured and examined for alkaline phosphatase levels and for the ability to produce mineralized nodules in culture. These are two characteristics of osteoblast-like cells in vitro. The levels of alkaline phosphatase produced by these cells were determined by a modified kinetic assay and the ability of these cells to produce mineral-like nodules in vitro was evaluated by Von Kossa staining and light and electron microscopy. PDL cells had significantly higher levels of alkaline phosphatase when compared with gingival fibroblasts obtained from the same patient and the same passage, in vitro. Furthermore PDL cells, but not GF, were capable of producing mineral-like nodules in vitro. These results indicate differences in behavior between PDL cells and GF; such differences may prove important in designing appropriate clinical therapies directed at stimulating periodontal regeneration. $J$ Periodontol 1991; 62:499-503.

Key Words: Periodontal attachment; connective tissue; fibroblasts; cells, periodontal ligament; cells, osteoblast-like.

The main goal for the treatment of periodontal diseases is the regeneration of lost cementum, bone, and soft connective tissue. Clinical ${ }^{1-3}$ and histological ${ }^{4}$ research suggests that it is possible to restore lost periodontal structures. Regeneration in vivo entails the migration of cells to the healing site and subsequent attachment, followed by proliferation, differentiation, and synthesis of mineralized and soft connective tissue components. These tissues, according to current evidence, are formed by cells which are derived from the remaining healthy portions of the periodontal connective tissues. ${ }^{5-7}$ In order to improve the success of clinical regenerative procedures, a better understanding of osteoblastlike properties of gingival fibroblasts and PDL cells in vitro is necessary.

Several researchers have evaluated biological properties of periodontal cells in culture, ${ }^{8-16}$ including their osteoblast-

\footnotetext{
Department of Periodontics, University of Maryland Dental School, Baltimore, MD.

${ }^{\star}$ Department of Pathology, University of Maryland Dental School Baltimore, MD.

${ }^{\ddagger}$ Currently: Department of Periodontics/Prevention and Geriatrics, University of Michigan Dental School, Ann Arbor, MI; previously, Department of Periodontology, University of Maryland Dental School, Baltimore, MD.
}

like properties. Criteria used for evaluating osteoblast-like properties of cells in vitro are: 1) the production of boneassociated products; i.e., bone matrix constituents, alkaline phosphatase; 2) expression of characteristic bone regulatory hormonal responses; i.e., increased production of AMP in response to parathyroid hormone (PTH) and increased synthesis of bone associated hormones in response to 1,25 dihydroxyvitamin $\mathrm{D}_{3}$; and 3) osteogenic capacity; i.e., can cells form mineralized nodules in vitro. ${ }^{17}$ Osteoblast-like properties reported for periodontal cells include high levels of alkaline phosphatase, ${ }^{12,14,16}$ production of greater than $95 \%$ type I collagen relative to other collagen types, ${ }^{10}$ and production of 2 bone-associated proteins, osteonectin ${ }^{18,19}$ and biglycan. ${ }^{19}$ However, these 2 proteins are not selective for mineralized tissues. ${ }^{17}$ In terms of hormonal responses, some laboratories have isolated a population of cells from the periodontal ligament that exhibit increased levels of cAMP in response to PTH, ${ }^{16,20}$ while other laboratories have not observed a PTH-mediated cAMP response in periodontal ligament cells in vitro. ${ }^{8,19}$

To further characterize the osteoblast-like properties of periodontal cells, cultures of human periodontal ligament (PDL) cells and gingival fibroblasts (GF) were evaluated for their ability to initiate mineralized nodules in vitro. $\mathrm{Al}$ - 
kaline phosphatase levels were also determined, since high alkaline phosphatase levels have been reported in cells that initiate nodules in vitro. ${ }^{21}$

\section{MATERIALS AND METHODS}

Connective tissue cells were obtained from the healthy gingiva and periodontal ligament of premolar teeth from individuals who underwent tooth extractions for orthodontic reasons, as detailed by Somerman et al. ${ }^{14}$ Periodontal status was determined by calibrated clinicians using the gingival index $(\mathrm{GI}),{ }^{22}$ plaque index (PI), ${ }^{23}$ probing measurements, and radiographic analysis to rule out the presence of bone loss, caries, or endodontic involvement. The tissue explants were maintained in culture media, Dulbecco's Modified Eagle Medium (DMEM) with $10 \%$ fetal bovine serum (FBS) supplemented with antibiotics. At confluency cells were transferred and designated as $\mathrm{T}_{1}$ (first passage). Cells were used in passages $T_{-}-T_{\|}$(first to eleventh passage).

\section{Alkaline Phosphatase}

PDL cells and GF were seeded at $\sim 2.0 \times 10^{5}$ cells/flask in DMEM with $10 \%$ FBS, $100 \mathrm{U} / \mathrm{ml}$ penicillin, $100 \mu \mathrm{g} / \mathrm{ml}$ streptomycin and $1.16 \mathrm{~g} / \mathrm{glutamine}$ at $37^{\circ} \mathrm{C}$ in a humidified atmosphere of $5 \%$ carbon dioxide, $95 \%$ air for 3 days. For each cell type 2 flasks were used to obtain cell counts, and 2 other flasks were used to measure alkaline phosphatase levels by a modified kinetic method (Sigma 245). Briefly, to measure alkaline phosphatase levels, medium was removed and cold $0.2 \% \mathrm{NP}-40$ in $2 \mathrm{mmol} / \mathrm{L} \mathrm{MgCl}_{2}$ was added to the cells. Flasks were maintained at $4^{\circ} \mathrm{C}$ for 15 minutes. Next the cells were freeze-thawed twice, sonicated and centrifuged for 10 minutes at $4000 \times \mathrm{g}$. To establish alkaline phosphatase levels, the supernatant was analyzed spectrophotometrically and data converted to units of alkaline phosphatase $\times 10^{-3} / 10^{6}$ cells. Differences in alkaline phosphatase levels were determined statistically by the student's $t$ test.

\section{Mineralization}

PDL cells and GF were seeded at a density of approximately 30,000 cells/well and cultured in DMEM containing 10\% FBS and antibiotics and supplemented with $50 \mu \mathrm{g} / \mathrm{ml}$ ascorbic acid, $10 \mathrm{mM}$ sodium $\beta$-glycerophosphate and $10^{-7} \mathrm{M}$ dexamethasone (stock solution in ethanol) or in control medium; i.e., DMEM, FBS, antibiotics, and $0.1 \%$ ethanol. This "supplemented" medium has been shown to induce mineralization in vitro. ${ }^{21,24-27}$ Cells were fed every 2 to 3 days, and between days 20 to 30 , cells were fixed with methanol and stained by the Von Kossa method, or embedded in EPON 812. Thick sections $(0.5-1 \mu)$ were stained with toluidine blue for light microscopy. Thin sections $(600 \AA)$ were stained with uranyl acetate/lead citrate to visualize the mineral nodules by electron microscopic examination. ROS $17 / 2.8$ cells were run routinely as positive controls. These cells have been studied extensively, and considered prototype osteoblast-like cells. ${ }^{17}$

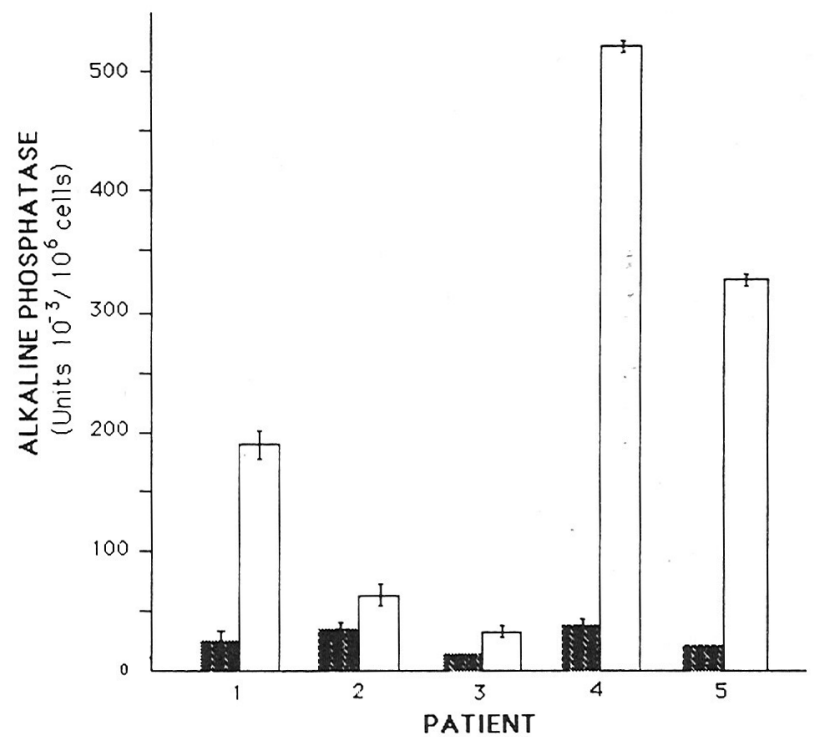

Figure 1. Alkaline phosphatase levels produced by paired $P D L$ cells and $G F$. $=G F ; \square=P D L$ cells. Bars $(I) \pm$ standard deviation. Students $\mathrm{t}$ test indicated that PDL cells had significantly higher activity when compared with that of $G F$.

\section{RESULTS}

Measurements of alkaline phosphatase levels indicated that PDL cells had significantly higher activity when compared with that of GF. This difference was seen when comparing paired (same patient, same passage) PDL cells and GF from 5 patients (Fig. 1).

PDL cells and ROS 17/2.8 cells were stimulated to produce mineral-like nodules when the cells were cultured in medium containing ascorbic acid, Na- $\beta$-glycerol phosphate, and dexamethasone. These nodules, however, were not identified as apatite by measuring calcium and phosphate ratios. The presence of mineral was ascribed to these deposits by light microscopy, following Von Kossa staining, as amorphous brown-black precipitates that distinguish calcium as inorganic phosphate. ${ }^{28}$ These nodules were observed to be associated with high densities of cells producing extracellular matrices as shown in Figure 2A. In contrast, gingival fibroblasts grown under the exact same condition failed to stain positively for nodules (Fig. 2B). These figures represent 1 study out of 4 separate experiments where cultures of PDL cells routinely demonstrated mineral-like nodule formation. In no situation did cultures of GF exhibit nodule formation. Electron microscopic examination of the mineral-like nodules revealed an electron dense amorphous material that decorated the surface of the extracellular matrices. The predominantly extracellular matrix component was collagen, although the characteristic $640 \AA$ periodicity was not readily visualized with this staining method. These electron dense particles were associated with individual groups of matrix fibers (Figs. 3A and B) and appeared to coalesce and grow into nodular structures homologous to the Von Kossa stained material observed with the light microscope. In no instance were these deposits, mineral nod- 

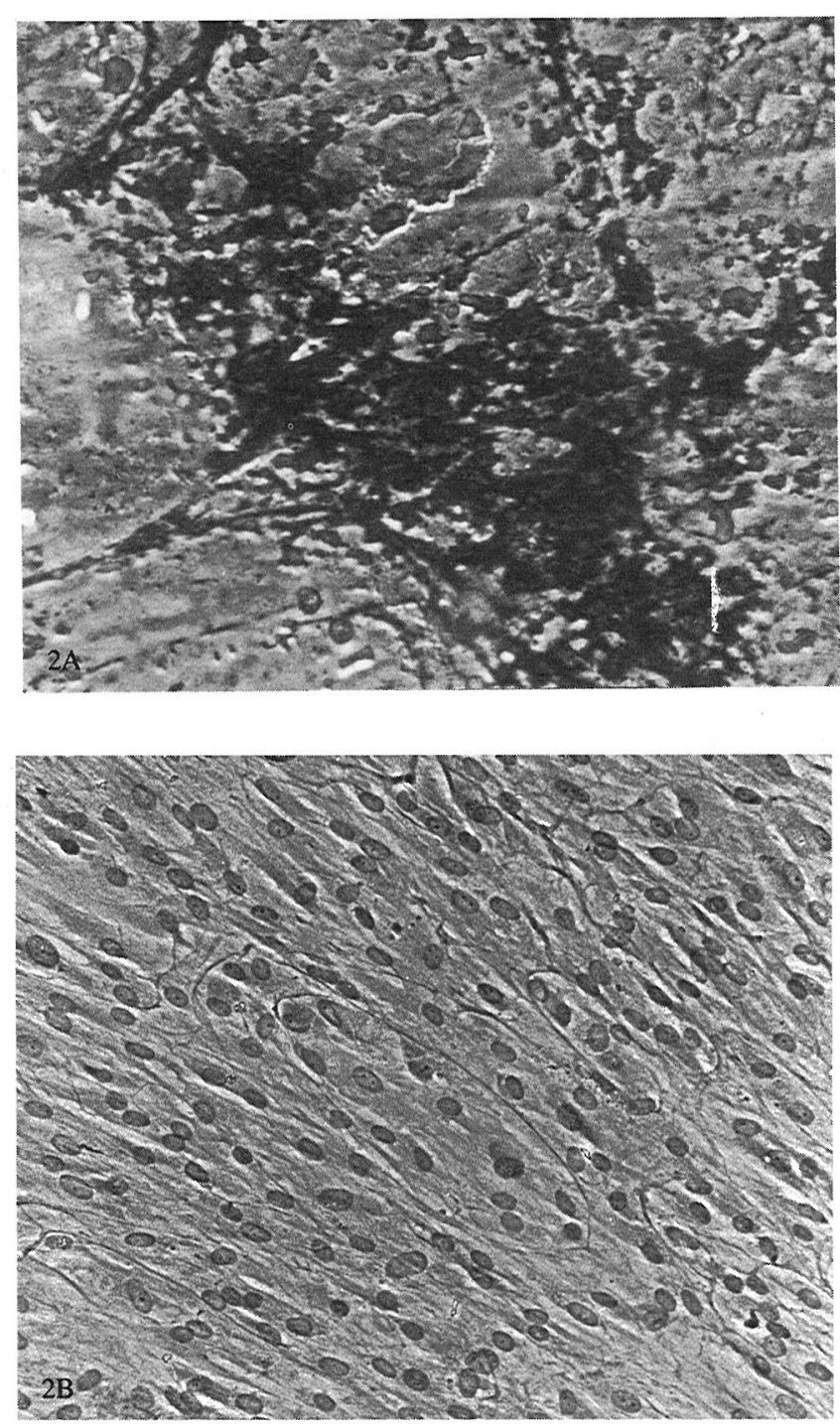

Figure 2.A. Von Kossa stained extracellular mineral nodules formed by PDL cells. Cell density is similar to Figure $2 B$ (original magnification $\times$ 32).

Figure 2.B. Von Kossa staining GF. Note absence of nodules (original magnification $\times 32$ ).

ules, intracellular or did they possess a crystal lattice structure characteristic of calcium phosphate precipitates from supersaturated solutions. Neither nodules or amorphous deposits of electron dense material of comparable size and morphology were observed in GF cultures (Fig. 3C) or when PDL and ROS 17/2.8 cells were cultured in medium lacking dexamethasone but containing the ethanol carrier (Fig. 3D).

\section{DISCUSSION}

The results of this study demonstrate that PDL cells, but not GF, can initiate mineral like nodules in vitro. Alkaline phosphatase levels were routinely higher in PDL cells compared with GF derived from the same patient; however PDL cells with high alkaline phosphatase (Fig. 1, patient 4) did not appear to exhibit more rapid or increased nodule for-
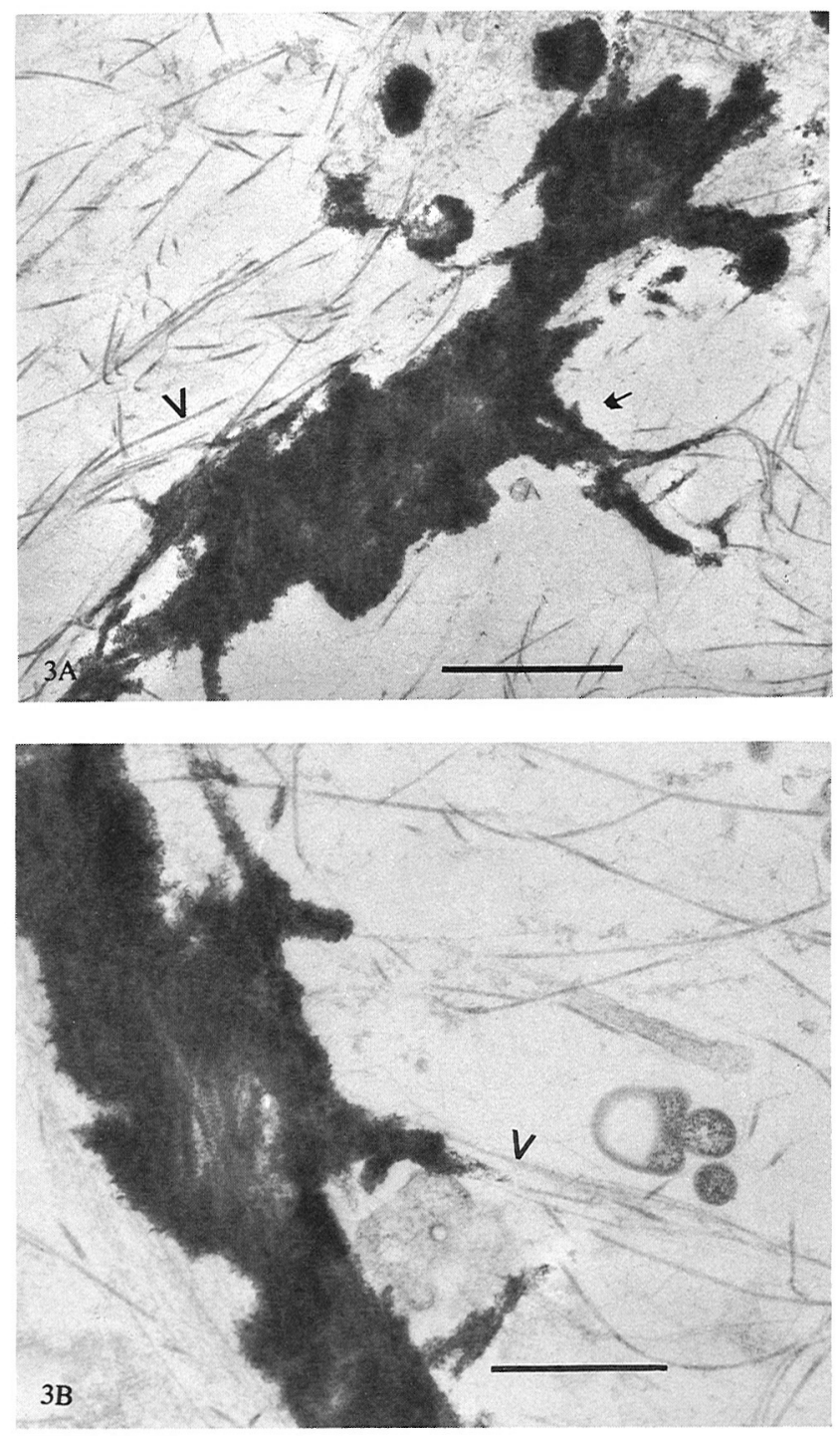

Figure 3.A. Mineralization in vitro. PDL cells produced mineralized nodules in vitro when cells were cultured in medium containing ascorbic acid, $\mathrm{Na- \beta}$-glycerophosphate, and dexamethasone. Mineral nodules $(\leftarrow)$ were associated with groups of collagen fibers $(<) ;($ bar, $1 \mu M=21.6 \mathrm{~mm})$ Figure 3.B. Higher magnification of mineral nodules in Figure 3.A to show structural details. (Bar, $1 \mu M=21.6 \mathrm{~mm})$

mation when compared with PDL cells with lower levels of alkaline phosphatase (Fig. 1, patient 3). Thus additional factors (properties), as yet to be determined, present in PDL cells, but not GF, may be important for initiating minerallike nodule formation in vitro. In addition, it is possible that alkaline phosphatase levels increase in all PDL cells during mineralization in vitro. Such levels were not determined in the present study.

Various studies have shown that mineralization occurs in monolayer cultures of osteoblasts in close association with collagen fibrils. This close association with collagen is reflective of the process of mineralization in vivo. ${ }^{21,24-27}$ In agreement with these studies we observed that mineral-like nodules were in close proximity to collagen fibrils, suggestive of a bone-like nature (Fig. 3A). 

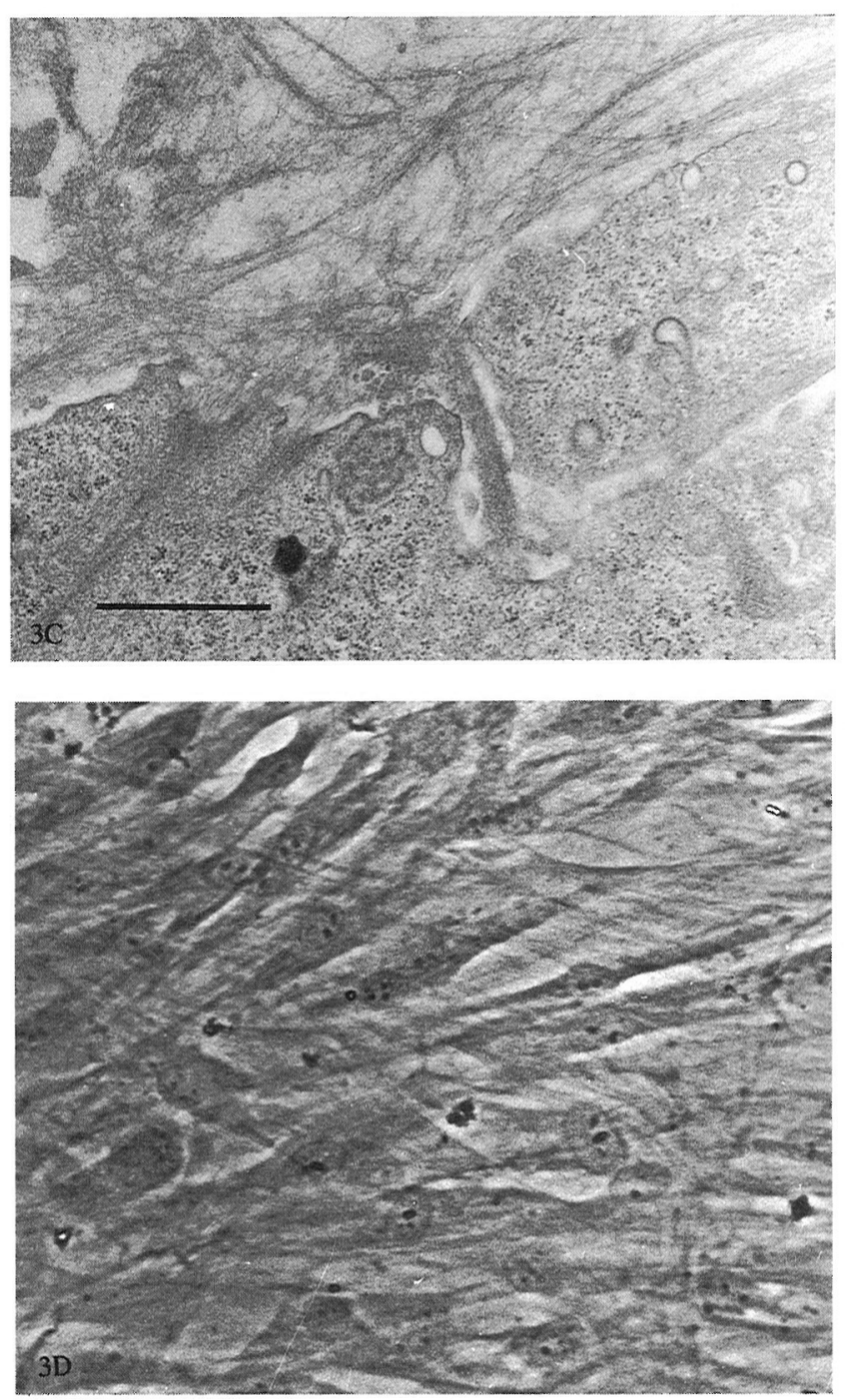

Figure 3.C. GF cultured exactly as PDL cells in Figure 3.A. No mineral nodules were observed. (Bar, $1 \mu M=21.6 \mathrm{~mm})$

Figure 3.D. Control of PDL cells treated with ethanol (original magnification $\times 32$ ).

Several factors may account for our findings that PDL cells, but not GF, form mineral-like nodules in culture and thus some caution must be taken in the interpretation of these in vitro studies. First, PDL cells and GF may be expressing a tissue culture dependent phenotype that may not represent the in vivo state. Second, the method used to obtain cultured PDL cells and GF and subculture these cells may select specific and dissimilar populations from each type of explant not representative of the in vivo situation. Third, the differences in cell function observed may be related to differences in aging; i.e., doubling times, between these two cell types in vitro. ${ }^{29}$ Doubling times were not determined in the studies described here. Lastly, PDL cells and GF may each have unique cell populations as suggested by several researchers. ${ }^{2,5,7}$ Most probably PDL cells and GF cultured from explants are heterogeneous populations of cells. ${ }^{30,31}$ However, regardless of such hetero- genecity, our studies suggest that PDL cells have different properties when compared with GF. Such properties; i.e., ability for PDL cells to initiate mineral-like nodules, may prove important when designing modalities of therapy directed at stimulating regeneration of the periodontium. Moreover, PDL cells in vitro may serve as a model for determining whether certain agents can initiate and enhance mineralization.

\section{Acknowledgments}

We thank Drs. Gerald M. Bowers and Mark Wagner for their advice, Leslie McLeary and Becky Wade for technical assistance, and Jo-Ann Walker for secretarial contributions. This work was supported in part by grants from the U.S. Public Health Service NIDR, NIH DE-09532 and DE-08648.

\section{REFERENCES}

1. Becker W, Becker B, Berg L, Prichard J, Caffessee R, Rosenberg E. New attachment after treatment with root isolation procedures: Report for treated class III and class II furcations and vertical osseous defects. Int J Periodontics Restorative Dent 1988; 8(3):2-16.

2. Pontoriero R, Lindhe J, Nyman S, Karring T, Rosenberg E, Sanavi F. Guided tissue regeneration in degree II furcation involved mandibular molars: A clinical study. J Clin Periodontol 1988;15:247254.

3. Schallhorn R, McClain P. Combined osseous composite grafting, root conditioning, and guided tissue regeneration. Int $J$ Periodontics Restorative Dent 1988; 8(4):9-32.

4. Bowers GM, Ganet M, Stevens M, et al. Histological evaluation of new attachment in humans: A preliminary report. $J$ Periodontol 1985;56:381-396.

5. Melcher AH. On the repair potential of periodontal tissues. $J$ Periodontol 1976;47:256-260.

6. Melcher $\mathrm{AH}$, Cheong $\mathrm{T}$. Fibroblast-like cells depress formation of bone-like tissues in vitro. J Dent Res 1988; 67(Spec. Issue):290 (Abstr. 1419A).

7. Nyman S, Gottlow J, Karring T, Lindhe J. The regenerative potential of the periodontal ligament. An experimental study in the monkey. $J$ Clin Periodontol 1982; 9:257-265.

8. Rao LG, Moe HK, Heersche JNM. In vitro culture of porcine periodontal ligament cells: Response of fibroblast-like and epithelial-like cells to prostaglandin $E_{1}$, parathyroid hormone and calcitonin and separation of a pure population of fibroblast-like cells. Arch Oral Biol 1978; 23:957-964.

9. Blomlof L, Otteskog P. Composition of human periodontal ligament cells in tissue culture. Scand J Dent Res 1981; 89:43-46.

10. Narayanan AS, Page RC. Connective tissues of the periodontium: A summary of current work. Collagen Rel Res 1983; 3:33-64.

11. Ragnarsson B, Carr G, Daniel JC. Isolation and growth of human periodontal ligament cells in vitro. J Dent Res 1985; 64:1026-1030.

12. Kawase T, Sato S, Yamada M, Hirayama A, Miake K, Saito S. Human periodontal ligament cells in vitro. Characterization of alkaline phosphatase. J Bone Min Res 1986;1(Suppl 1):63A.

13. Ross GG, Yamasaki A, Pinero GJ, Mahan CJ. Human periodontal ligament cells, in vitro. J Periodont Res 1987; 22:75-77.

14. Somerman MJ, Archer SY, Imm GR, Foster RA. A comparative study of human periodontal ligament cells and gingival fibroblasts in vitro. J Dent Res 1988; 67:66-70.

15. Otsuka K, Pitara S, Overall CM, Aubin JE, Sodek J. Biochemical comparison of fibroblast populations from different periodontal tissues: Characterization matrix protein and collagenolytic enzyme synthesis. Biochem Cell Biol 1988; 66:167-176. 
16. Piche JE, Carnes DL, Graves DT. Initial characterization of cells derived from human periodontia. J Dent Res 1989; 68:761-767.

17. Majeska RJ, Rodan GA. Culture and activity of osteoblasts and osteoblast-like cells. In: Butler WT, ed., The Chemistry and Biology of Mineralized Tissues. Birmingham, AL: Ebsco Media, Inc. 1985: 279.

18. Wasi S, Otsuka K, Yao K-L, et al. An osteonectin-like protein in porcine periodontal ligament and its synthesis by periodontal ligament fibroblasts. Can J Biochem Cell Biol 1984; 62:470-478.

19. Somerman MJ, Young MA, Foster RA, Moehring JM, Imm G, Sauk JJ. Characteristics of human periodontal ligament cells in vitro. Arch Oral Biol 1990;35:241-247.

20. Roberts WE: Cell population dynamics of periodontal ligament stimulated with parathyroid extract. Am J Anat 1975; 143:363-370.

21. Ecarot-Charrier B, Shepard N, Charette G, Goynpass M, Glorieux FH. Mineralization in osteoblast cultures: A light and electron microscopic study. Bone 1988; 9:147-154.

22. Löe H, Silness J. Periodontal diseases in pregnancy I. Prevalence and severity. Acta Odontol Scand 1963; 21:533-551.

23. Silness J, Löe H. Periodontal diseases in pregnancy II. Correlation between oral hygiene and periodontal condition. Acta Odontol Scand 1964; 22:121-142.

24. Tenebaum HC, Heersche JNM. Differentiation of osteoblasts and formation of mineralized bone in vitro. Calcif Tissue Int 1982; 34:7679.
25. Gerstenfeld LC, Chipman SD, Glowacki J and Lian JB. Expression of differentiated function by mineralizing cultures of chicken osteoblasts. Dev Biol 1987; 122:49-60.

26. Bellows CG, Aubin JE, Heersche JNM. Physiological concentrations of glucocorticoids stimulate formation of bone nodules from isolated calvaria cells in vitro. Endocrinology 1987; 121:1985-1992.

27. Bhargava U, Bar-Lev M, Bellows CG, Aubin JE. Ultrastructural analysis of bone nodules formed in vitro by isolated rat calvaria cells. Bone 1988; 9:155-163.

28. Lillie RD. Histopathological Technique and Practical Histochemistry. 3rd ed. McGraw Hill Book Co. 1965.

29. Vogel KG, Kelley RO, Stewart C. Loss of organized fibronectin matrix from the surface of aging diploid fibroblasts (IMR-90). Mech Ageing Devel 1981; 16:295-302.

30. McCulloch GAG. Progenitor cells populations in the periodontal ligament of mice. Anat Rec 1985; 211:258-262.

31. Ko SD, Page RP, Narayanan AS. Fibroblast heterogeneity and prostaglandin regulation of subpopulations. Proc Natl Acad Sci (USA) 1977; 74:3429.

Send reprint requests to: Dr. John Sauk, University of Maryland Dental School, Department of Pathology, Room 4-A-28, 666 West Baltimore St. Baltimore, MD 21201.

Accepted for publication February 27, 1991. 